\title{
Discussion on the Innovation and Entrepreneurship Education Reform in Colleges and Universities Against the Background of "Dual Innovation"
}

\author{
Jiancui Ma \\ Hunan Modern Logistics College \\ Changsha, China
}

\author{
Jing Zhong* \\ Hunan Modern Logistics College \\ Changsha, China \\ *Corresponding Author
}

\begin{abstract}
College students are one of the groups with the most potential for innovation and entrepreneurship. Colleges and universities' cultivating the ability of college students to innovate and start business, and carrying out education on innovation and entrepreneurship is a major strategic measure for the education system to thoroughly study and practice the scientific development concept and serve the construction of an innovative country, an important way to deepen the reform of education and teaching, cultivate students' innovative spirit and practical ability, and improve students' self-development ability, and an important measure to implement employment by entrepreneurship to promote full employment of college graduates. In the reform of innovation and entrepreneurship education, universities should start with the curriculum teaching methods and content, and the evaluation system of innovation and entrepreneurship education, and implement innovation and entrepreneurship in teaching practice.
\end{abstract}

Keywords-innovation and entrepreneurship; classroom teaching methods; evaluation system

\section{INTRODUCTION}

Dual innovation education is a demand for the development of the times, an embodiment of the quality of market talents, and a demand for the development of science and technology in China. The educational reform of innovation and entrepreneurship in colleges and universities is an urgent need for the country to implement an innovationdriven development strategy and promote economic quality and efficiency upgrades. It is also an important measure to promote comprehensive reform of higher education and promote higher quality entrepreneurship and employment for college graduates. As a window for talent cultivation in the market, universities should strengthen the management of innovation and entrepreneurship education, integrate dual innovation education into the classroom, and evaluate them, cultivate teachers who are in line with dual innovation education, building a platform for the cultivation of dual talents.

\section{ANALYSIS OF TALENT CULTIVATION IN INNOVATION AND ENTREPRENEURSHIP IN COLLEGES}

\section{A. Background of Dual Innovation Talent Cultivation}

"Mass entrepreneurship and innovation" is a "dual engine" that pushes China's economy forward. The current dual innovation strategy is an important concept of China's education management science, and it is also the main driving force for China's socio-economic sustainable growth The development of modern science and technology, as well as the demand for talents in the national industry are the driving forces for the dual-creative talent training. Industry needs point the way for the development of science and technology, and development of science and technology puts forward clear standards and requirements for talent training needs. Dual innovation education is a demand for talent training in the industry. Moreover, the in-depth development of higher education reform can promote the quality of dual innovation talent training, provide motivation for scientific and technological development, and meet the development needs of the country.

\section{B. The Status of China's "Dual Innovation" Education}

Dual innovation education also sets new requirements for higher education. Therefore, the reform of college education is the demand of the times and the market. In order to train dual innovation talents, colleges and universities need to deeply understand the actual needs of the market and take various forms to integrate dual innovation education into the education process. Colleges and universities can set up innovation and entrepreneurship courses, organize innovation and entrepreneurship associations, participate in innovation and entrepreneurship competitions, conduct entrepreneurship lectures, and start entrepreneurial practice activities to launch innovation and entrepreneurship education.

At present, dual innovation education in colleges and universities is at an exploratory stage. Although it has been developed in various forms, it is still in a form of education process that only increases the content of innovative education. It does not create an atmosphere of mass 
with professional education and developed in concert with professional education.

The learning of professional knowledge is a progressive process, from cognition to familiarity to refinement and specialization. In this progressive process, schools should consider cultivating students' innovative and entrepreneurial capabilities as a progressive process, integrate it into the process of professional education, and develop in concert with professional education. First of all, during the period when students are familiar with professional knowledge, students must be informed about the current market conditions and existing problems of the majors, and with the rapid development of society and the rapid development of science and technology, what are the development trends of the industry? Schools need to cultivate students 'interest in exploring the frontiers of industry development, and cultivate students' innovative ideas and consciousness. With the indepth understanding of professional knowledge, students can have a certain ability to analyze problems and solve problems in the field of professional knowledge. At this time, schools should be problem-oriented, allowing students to conduct in-depth investigations into enterprises, let them find problems in the enterprise, and make solutions to the problems, as well as find new directions and trends in the development of the industry, and cultivate students' innovative ideas, and awareness. Finally, the maturity of students' knowledge and ideas should be educated in a project-driven mode. The school connects the actual business of the industry, allows students to participate in the project implementation process, and cultivates students' love for the profession and industry from the project implementation process. Schools should formulate professional assessment and evaluation systems, cultivate students' professional ethics on the job, hone students' will, and cultivate students' innovative and entrepreneurial abilities under the guidance of teachers and continuous pursuit of answers to questions.

\section{DEEP INTEGRATION OF THE ABILITY OF INNOVATION AND ENTREPRENEURSHIP AND CLASSROOM TEACHING}

Colleges and universities are a transitional stage for students to enter society, and they are an important part of students' transition from basic knowledge to professional knowledge. For professional docking industry, learning docking employment and entrepreneurship, great changes will take place in learning and thinking. Integrating the ability of dual innovation into the teaching process is the key link of the ability of dual innovation.

\section{A. Teaching Organization Design for Cultivating the Ability of Dual Innovation}

The cultivation of dual innovation capabilities requires innovation capabilities and entrepreneurial capabilities. Innovative ability means knowledge innovation ability. It needs the design of teaching organization to train students' reading and decision-making ability, innovation experience accumulation, team collaboration ability, investment and management ability, and thinking innovation ability. Entrepreneurial ability is the cultivation of knowledge transfer and creative ability. It needs to cultivate students' 
analytical problem and decision-making ability, grasp of opportunity, commitment ability, financing and management ability, communication and negotiation ability, operation ability and conception ability in the teaching organization design. So that students can have the impulse and action to start a business.

\section{B. Teaching Methods for Cultivating Dual Innovation Ability}

The method of developing dual innovation is studentcentered. At present, there are a series of teaching methods adopted with the development of information technology such as MOOC, micro-learning, online courses, and mixed education. The generation of teaching methods corresponds to the current era background, corresponds to the living environment of students, and adapts to their methods of receiving new knowledge and new things. Whether it is MOOC, micro-learning or online course, it can satisfy students 'autonomous learning online, and can cultivate students' autonomous learning ability. However, the effect of autonomous learning still needs to be supervised and evaluated in the classroom of the school. The key is to disambiguate and guide properly. Micro-learning, MOOC, and online teaching resources should not be a means for teachers to simplify the teaching process of classroom teaching, but should be online learning resources for students after class. Teachers use the classroom teaching method to allow students to learn new knowledge outside the classroom, internalize the knowledge through discussion and communication in the classroom, and solve doubts during learning. Teachers give students proper guidance based on the discussion process.

Through the online learning of the course, students' selflearning ability and self-control and self-management ability are cultivated. Through classroom discussions and exchanges, the school urges and evaluates students' learning effects, and gives certain evaluations. The professional ethics training of docking positions hones the psychological quality of students, allowing them to undergo the training of frustration and victory test. The school adopts the teaching method of flipping the classroom. In the classroom, the school completes the internalization of the learned knowledge through the methods of full communication, collaborative exploration and scientific experimentation, and leads to new problems and new knowledge needed to be learned, cultivates students' expression and communication skills, teamwork skills, and the ability to concentrate on research.

\section{Integration of Dual Innovation Quality and Teaching Content}

The process of dual innovation is: awareness of innovation and entrepreneurship - development of innovation and entrepreneurship - transformation of innovation and entrepreneurship results. To cultivate innovative and entrepreneurial talents, innovation and entrepreneurship should be integrated with teaching content in the teaching process. Innovative knowledge education, professional innovation and entrepreneurship competitions, evaluation of the use of professional knowledge, evaluation of the use of interdisciplinary expertise, applications for professional intellectual property rights, and applications for innovative projects should be properly arranged in the design of the teaching system. Schools need to encourage students to actively participate in the team of innovation and entrepreneurship, build a base for innovation and entrepreneurship, create a workplace atmosphere for innovation and entrepreneurship, establish an evaluation system for innovation and entrepreneurship, and allow students to participate in practice places on and off campus, complete the docking of professional knowledge and practical operations, complete the transformation of the results of innovation and entrepreneurship, and the continuous exploration of professionalism.

\section{CONSTRUCTION OF THE EVALUATION SYSTEM OF DUAL INNOVATION EDUCATION}

The effect of the innovation education requires a series of evaluation systems to urge and encourage. The construction of a dual innovation education evaluation system can also reflect the status and importance of dual innovation education. The construction of an incentive mechanism can stimulate the enthusiasm of teachers and students to participate.

\section{A. Evaluation System of Dual Innovation Education}

In order for dual innovation education to be integrated into the teaching process and become a normal state, the evaluation elements and methods of dual innovation education should be reflected in the evaluation system. The assessment of the knowledge of innovation and entrepreneurship in the early stage should be completed at the end of freshman year to evaluate students' knowledge of innovation and entrepreneurship. It is necessary to evaluate the participation of innovation and entrepreneurship projects, and to evaluate the problems and solutions proposed by the enterprises that have investigated the status of the industry development. The evaluation of the patent application of professional knowledge is used as an evaluation system for innovation and entrepreneurship, and it is included in each link of teaching for evaluation. It is necessary to conduct a systematic assessment and evaluation of the construction of teachers' innovation and entrepreneurship teams, and urge teachers and students to jointly create a team learning atmosphere for innovation and entrepreneurship.

\section{B. Incentive Mechanism for Dual Innovation Education}

The virtuous circle of innovation and entrepreneurship education requires a reasonable incentive mechanism. For the construction of teacher innovation teams, schools need to introduce a teacher training incentive mechanism that combines relevant theoretical learning with corporate practice, encourages teachers to go deep into the enterprise for practical learning, encourages teachers to enter professional seminar training venues, and delve into professional knowledge. For students, it is necessary to build an innovation and entrepreneurship base and an achievement conversion platform, so that the students' innovation and 
entrepreneurship achievements can be realized, and their passion can be improved.

\section{CONCLUSION}

Innovation and entrepreneurship education reform is the need of social development and the need of market development. The cultivation of innovation and entrepreneurship requires universities to assume the primary responsibility, but the strength of universities alone cannot truly create a campus atmosphere of innovation and entrepreneurship. It also requires the strong cooperation of enterprises. A good platform for innovation and entrepreneurship enables dual innovation education to begin with college students, cultivate their awareness of innovation and ability, create a good atmosphere for innovation and entrepreneurship, provide students with dual innovation opportunities, and provide dual innovation logistics support services and results conversion platforms, making innovation and entrepreneurship be implemented into actual actions and actual results, so that students can truly embark on the track of entrepreneurship and employment.

\section{REFERENCES}

[1] Wang Ronghui, Xing Kunlun. Deconstruction of Talent Capacity of "Dual Innovation" and System of Training Elements [J]. China Vocational and Technical Education, 2018, (18), 29-33. (in Chinese)

[2] Li Ran, Jiang Qianqian, Liu Huanhuan. Approaches, Models and Promotion Strategies for College Students' Innovation and Entrepreneurship Education [J]. Journal of Jilin TV Radio University, 2019, (10) 83-84. (in Chinese)

[3] Cheng Yuanyuan, Analysis of the Construction of University Innovation and Entrepreneurship Education System under the Dual Innovation Environment [J]. Chinese \& Foreign Entrepreneurs, 2019, 10. (in Chinese)

[4] Ma Mingxu, Zhang Wenlei. Research on the Collaborative Innovation Mechanism of "Dual Innovation" Talent Training [J]. China Market, 2019 (28), 178-179. (in Chinese) 